\title{
The Kostënki 18 child burial and the cultural and funerary landscape of Mid Upper Palaeolithic European Russia
}

Natasha Reynolds ${ }^{1,2, *}$, Rob Dinnis ${ }^{2,3, *}$, Alexander A. Bessudnov ${ }^{3, *}$, Thibaut Devièse $^{2} \&$ Thomas Higham ${ }^{2}$

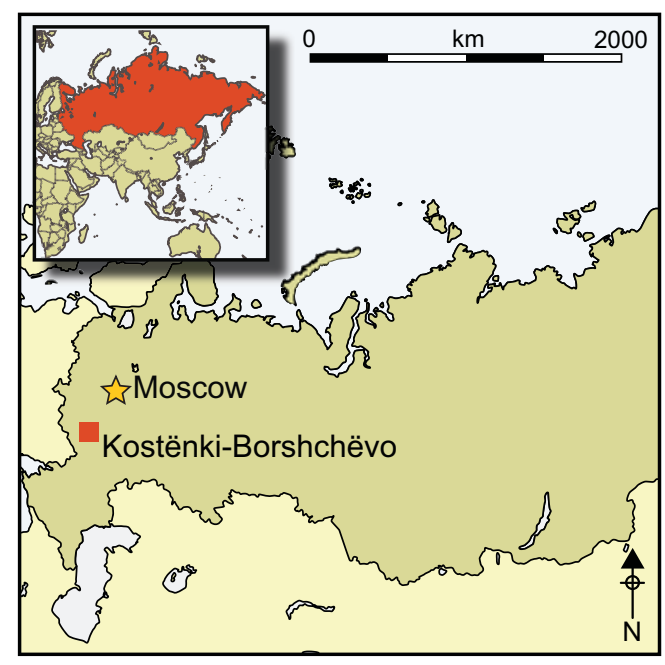

Palaeolithic burials are few and far between, and establishing their chronology is crucial to gaining a broader understanding of the period. A new programme of radiocarbon dating has provided a revised age estimate for the Palaeolithic burial at Kostënki 18 in European Russia (west of the Urals). This study reviews the need for redating the remains, and contextualises the age of the burial in relation to other Upper Palaeolithic funerary sites in Europe and Russia. The new date, obtained using a method that avoided the problems associated with previous samples conditioned with glue or other preservatives, is older than previous estimates, confirming Kostënki 18 as the only plausibly Gravettian burial known in Russia.

Keywords: Russia, Upper Palaeolithic, Gravettian, radiocarbon dating, funerary archaeology

\section{Introduction}

The Upper Palaeolithic record of European Russia is dominated by the KostënkiBorshchëvo complex of sites, approximately $40 \mathrm{~km}$ south of Voronezh (Figure 1). A total of 26 open-air Upper Palaeolithic sites have been found there, in and around the villages of Kostënki and Borshchëvo on the west side of the River Don. As well as being individually named, each of these sites is referred to by a number: Kostënki 1-21 and Borshchëvo 1-5

1 UMR 5199 PACEA, Université de Bordeaux, Bâtiment B8, Allée Geoffroy Saint Hilaire, CS 50023, 33615 Pessac Cedex, France

2 School of Archaeology, University of Oxford, 1-2 South Parks Road, Oxford OX1 3UB, UK

3 Institute for the History of Material Culture, Dvortsovaia naberezhnaia 18, 191186 Saint Petersburg, Russia

* Authors for correspondence (Email: natasha.reynolds@u-bordeaux.fr; rdinnis@britishmuseum.org; alexander.bessudnov@gmail.com) 


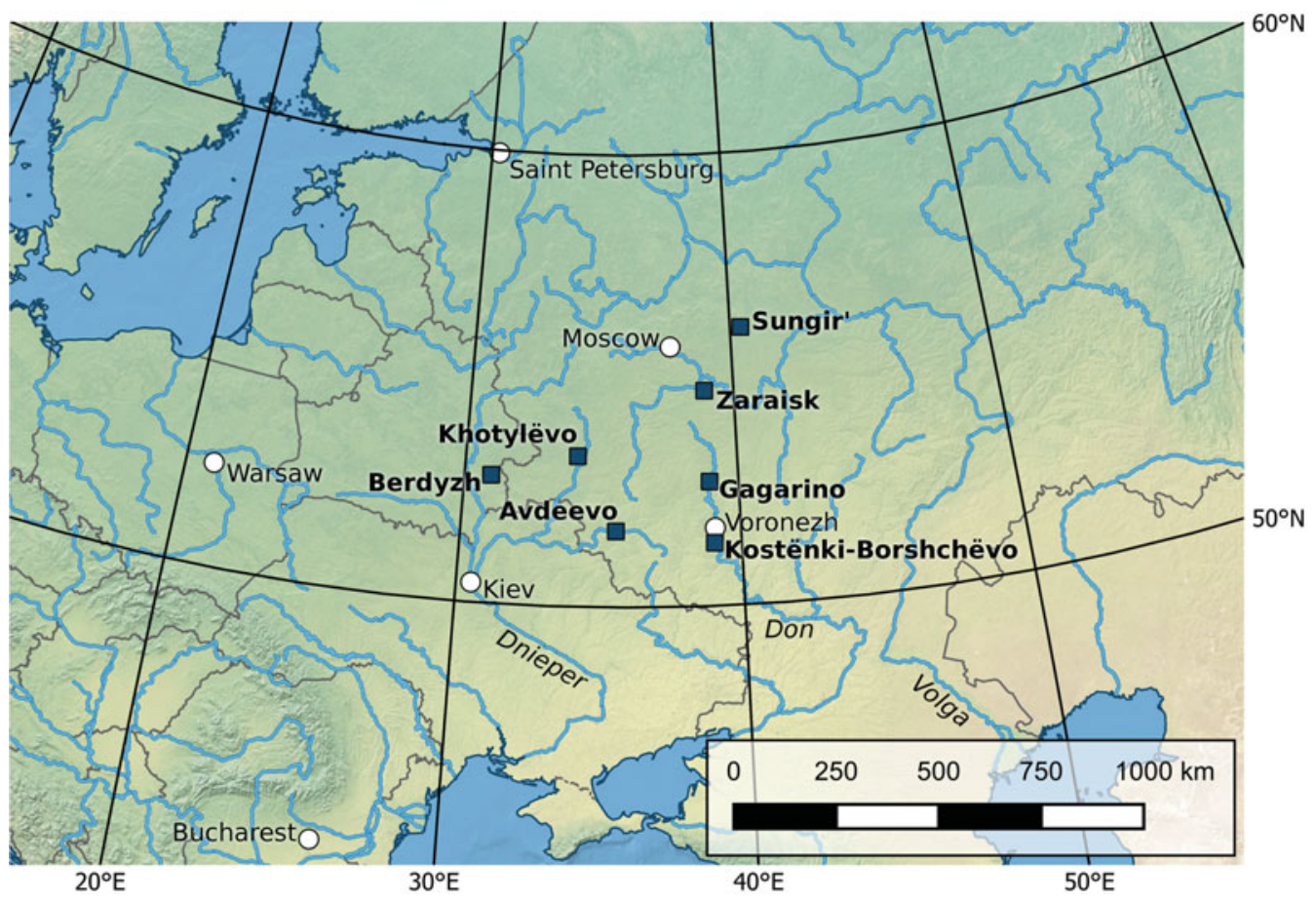

Figure 1. Map showing the locations of Russian and Belarusian sites mentioned in the text.

(Figure 2). More than half of the sites have yielded archaeological material from at least one period of the Mid Upper Palaeolithic (MUP; c. $30-22{ }^{14} \mathrm{C}$ kya BP) (Praslov \& Rogachëv 1982; Sinitsyn 2007, 2015).

In European Russia, as across Europe, most MUP archaeological assemblages are described as Gravettian. The definition and usage of the term Gravettian has a complex history, and today is used inconsistently (Peña Alonso 2012; Noiret 2013; Pesesse 2013). For some it is a chronological designation used synonymously or near synonymously with MUP; for others it helps to describe an assemblage's contents. We incline towards the latter viewpoint, and suggest that the term Gravettian be reserved for MUP assemblages that include the systematic production of backed lithic artefacts, including Gravette points, microgravettes and shouldered points. A significant proportion of Russian MUP assemblages do not meet this definition of Gravettian (Djindjian et al. 1999; Noiret 2013; Sinitsyn 2015).

A notable feature of the European MUP is the relative abundance of human burials, especially in comparison with the preceding Early Upper Palaeolithic (EUP), and connections between Gravettian assemblages and human burials have been repeatedly emphasised (e.g. Formicola 2007; Henry-Gambier 2008; Pettitt 2011; Riel-Salvatore \& Gravel-Miguel 2013). Numerous MUP single and multiple burials have been found, many of which contained large amounts of ochre, items of personal ornamentation and grave goods. Well-known examples include those from Dolní Věstonice (Czech Republic), the (C) Antiquity Publications Ltd, 2017 


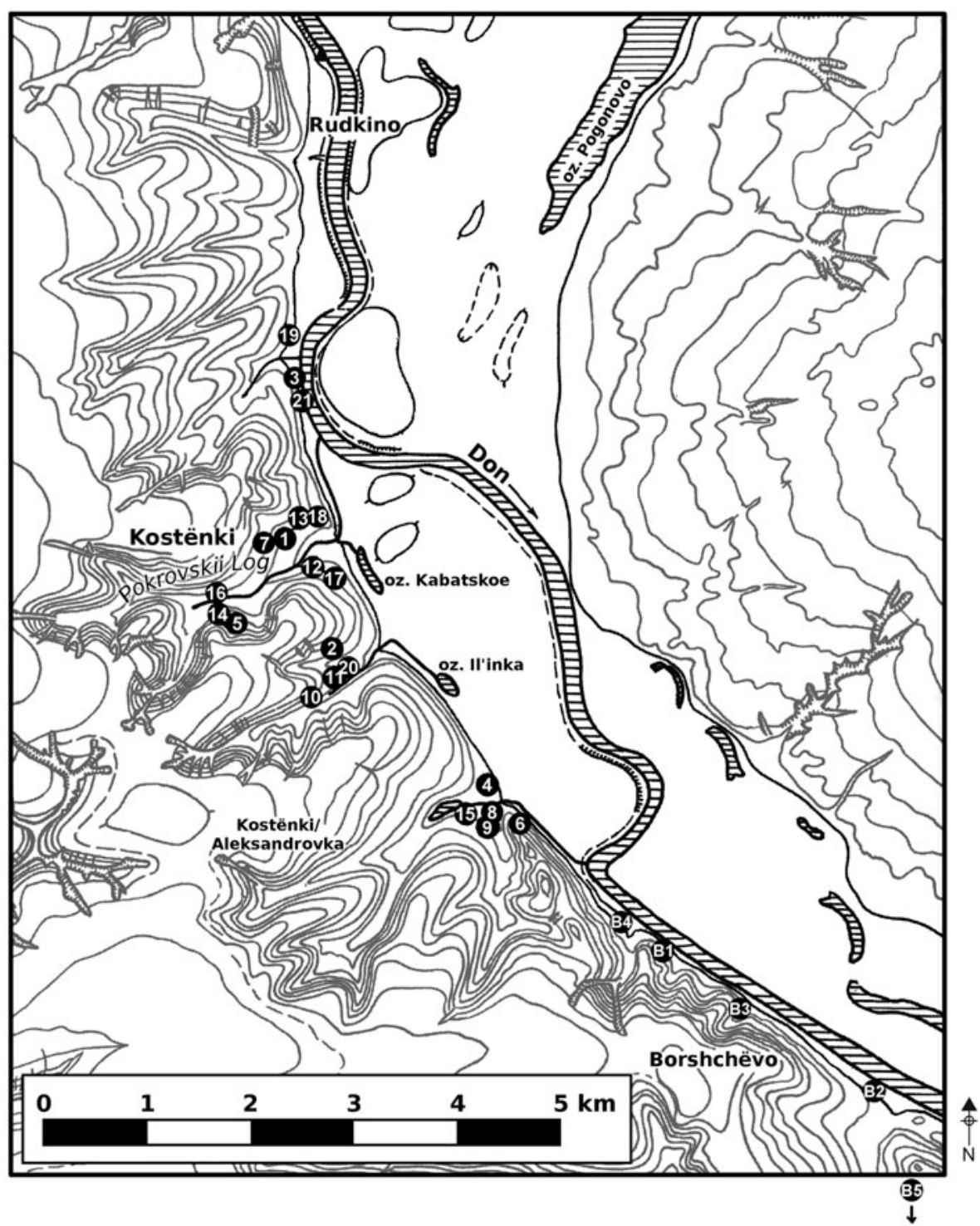

Figure 2. Map showing the locations of the Kostënki-Borshchëvo Upper Palaeolithic sites (sites 1-21 refer to the Kostënki sites, while sites B1-B5 refer to the Borshchëvo sites). Contour interval: 10m. (Modified (with permission) after map by I.I. Krasnov, in Praslov \& Rogachëv 1982.)

Balzi Rossi (Grimaldi) Caves (Italy) and Krems-Wachtberg (Austria) (Klima 1988; Mussi 1995; Einwögerer et al. 2008).

The best-known Russian Palaeolithic burials - and some of the most extraordinary discoveries of the entire Upper Palaeolithic-were found at Sungir', almost 200km east of Moscow (Figure 1) (Bader 1967, 1970; Bader \& Lavrushin 1998; Trinkaus et al. 2014). The record of EUP/MUP funerary activity elsewhere in European Russia is confined to the Kostënki-Borshchëvo sites, and is less well known internationally. Burials have been found 


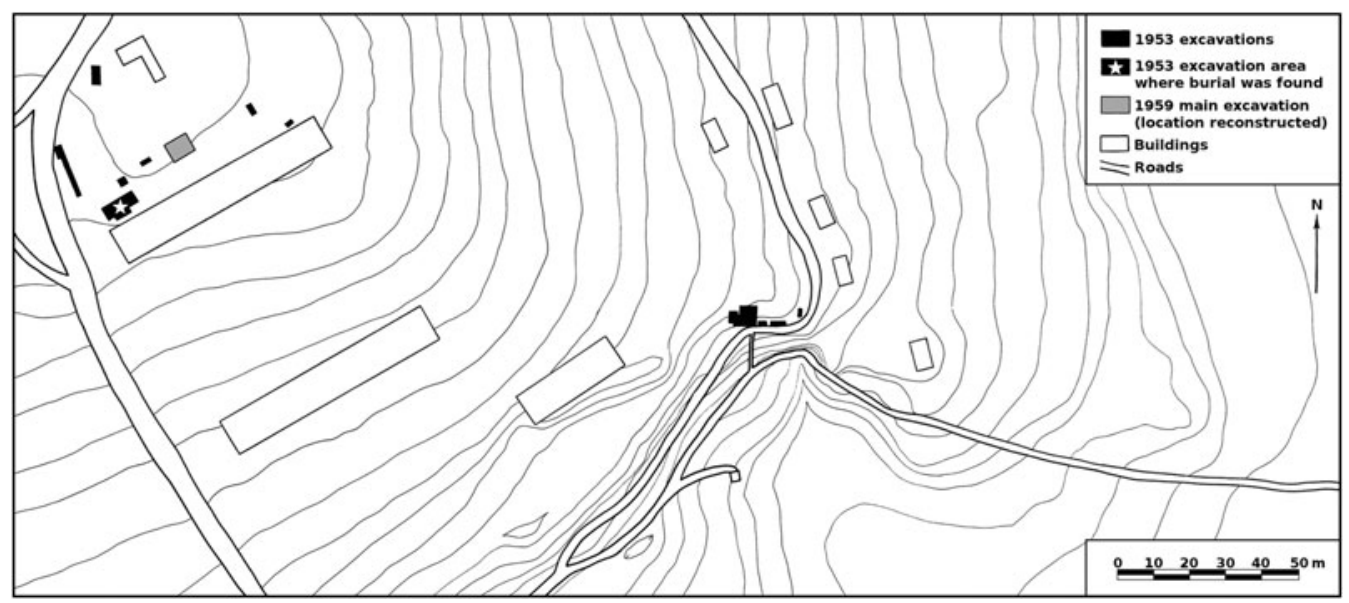

Figure 3. Map showing the locations of the Kostënki 18 excavations. The location of the 1953 excavations and buildings are based on the original plans from the excavation report (Rogachëv 1959). The location of the principal 1959 excavations has been reconstructed based on excavation square numbers and cannot be regarded as definitive. Contour interval: $1 \mathrm{~m}$. (Modified after a figure by A.N. Rogachëv, IIMK RAN Archives, 1953, photograph number: 0.2068-13, published with permission of IIMK RAN.)

at Kostënki 2, 12, 14 and 15, while fragmentary human remains have been found at several other sites (Gerasimova 1982; Sinitsyn 2004; Gerasimova et al. 2007). As outlined below, some of these burials apparently date to the MUP, while others date to the EUP. None, however, are associated with a Gravettian lithic assemblage.

Finally, there is also the burial of a child found at Kostënki 18. The main archaeological layer at Kostënki 18 is attributed to the late Gravettian 'Kostënki-Avdeevo Culture' due to its lithic assemblage (Rogachëv \& Beliaeva 1982), and a connection between the burial and this archaeological layer has been assumed but not firmly demonstrated. Here, we reassess Kostënki 18 in the light of a new radiocarbon date for the burial, and consider its status as the only plausibly Gravettian burial in Russia.

\section{Kostënki 18}

Kostënki 18 (also known as Khvoikovskaia) is located close to the mouth of Pokrovskii Log ravine, around $200 \mathrm{~m}$ from Kostënki 13 and $400 \mathrm{~m}$ from Kostënki 1 (Figure 2). The site was discovered by A.N. Rogachëv in 1953 during investigation into construction work. At this time, the child burial was identified and excavated along with several other archaeological features, including Palaeolithic pits. A total of approximately $115 \mathrm{~m}^{2}$ was dug that year across several locations up to around $200 \mathrm{~m}$ apart (Figure 3). Later, in 1959, four small test-pits were dug, one of which was subsequently enlarged in the same season to a $7 \times$ $6 \mathrm{~m}$ excavation area. The 1959 fieldwork established the presence of a sizeable layer of Palaeolithic material (covering almost the entire area of the $7 \times 6 \mathrm{~m}$ excavation) (Rogachëv \& Beliaeva 1982).

The Kostënki 18 grave and its contents were badly affected by earthworks made during the mid twentieth century and earlier. By the time the burial was identified and (C) Antiquity Publications Ltd, 2017 
excavated by archaeologists, a significant part of the grave and the surrounding area had been destroyed on both sides (Figures 4-6), and only the north-eastern edge of the

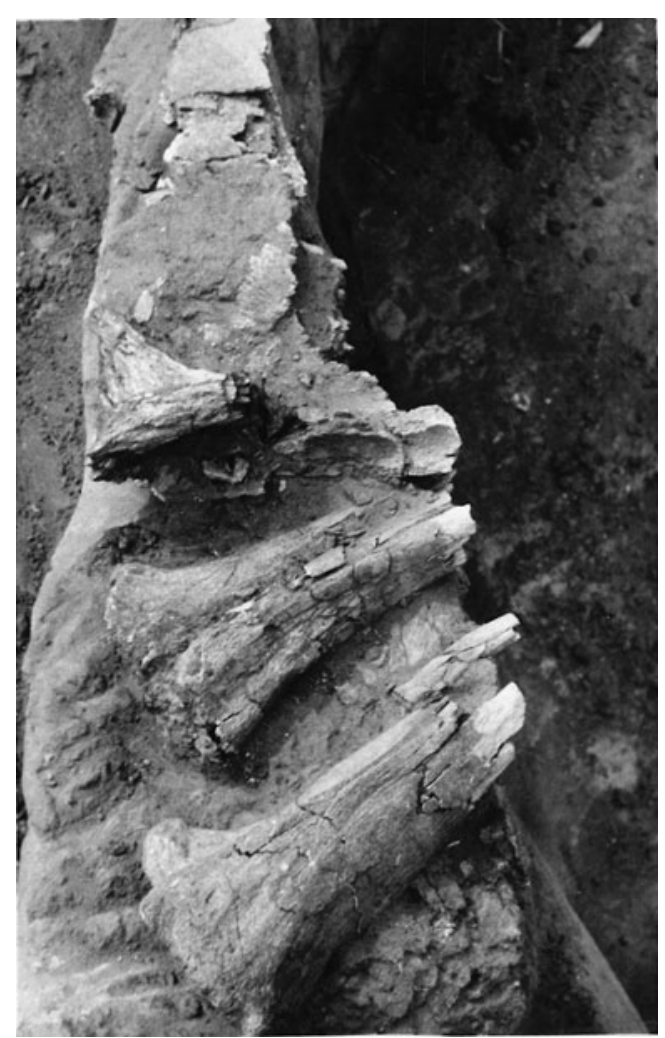

Figure 4. Photograph showing mammoth bones constituting part of the grave fill at Kostënki 18 (photograph: Rogachëv 1953, IA RAN Archives F.1 R.1 number 850, fig. 17, published with permission of IA RAN). original grave pit was found to be intact. The undisturbed portion of the grave was sub-triangular in form and measured around $1.2 \times 0.52 \mathrm{~m}$, although the original size and shape of the grave cut are unknown. The base of the grave could only be delineated by the location of the skeletal remains: Rogachëv was unable to define a cut or any other sediment change (Rogachëv 1955; Rogachëv \& Beliaeva 1982).

Within the burial pit were the remains of a child, originally assessed as being around 6-7 years of age (Rogachëv 1955), and later as around 9-10 years old (Gerasimova 1982). The individual had apparently been laid in a partially flexed position on their left side with the head oriented towards the south-west, facing north-west (Figures 4-7). The skeleton was incomplete-in particular, the limb bones had been destroyed distally from the mid humeri and mid femora (Rogachëv 1955; Rogachëv \& Beliaeva 1982).

Above the human remains were three layers, $0.35 \mathrm{~m}$ thick in total, of badly decayed mammoth bones and tusks in various artificial arrangements. These had been partially destroyed prior to Rogachëv's investigation (Figure 4) but were interpreted as having formed part of the grave deposit (Figure 7). The uppermost layer was made up of a dense arrangement of bones and tusk fragments, lying perpendicular to the child's torso. Below this was a similar series of bones lying in approximately the same orientation as the torso. In the lowermost layer were two fragments of scapula, positioned above the child's head and chest, and two long bones found at an angle to those in the overlying layer (Rogachëv 1955; Rogachëv \& Beliaeva 1982).

With the exception of the mammoth bones, no grave goods were found, and no ochre or charcoal was identified in association with the human remains. No in situ Palaeolithic cultural layer was found in the grave's immediate vicinity and, although Rogachëv estimated the original grave pit to be at least $0.4 \mathrm{~m}$ deep, he was not able to determine the original level from which the pit had been dug (Rogachëv \& Beliaeva 1982). The precise stratigraphic relationship between the burial and the other archaeological remains at Kostënki 18 is therefore impossible to establish. 


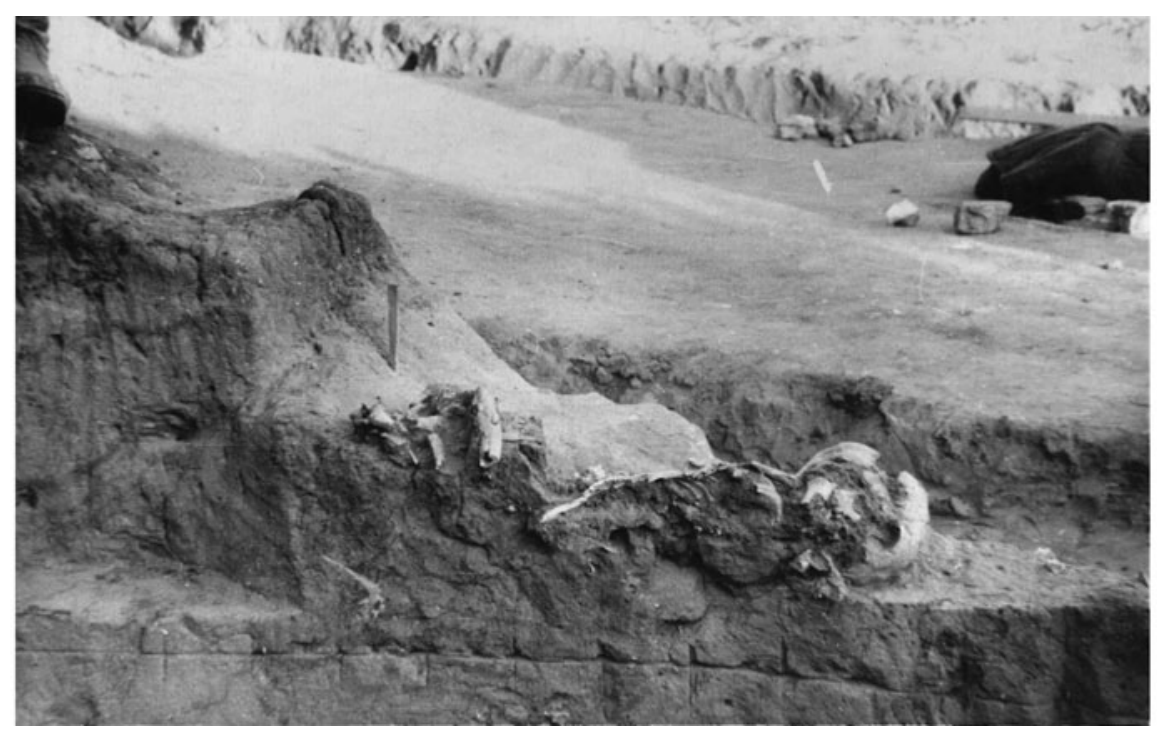

Figure 5. Photograph showing the Kostënki 18 human remains (view from the north-west) (photograph: Rogachëv 1953, IA RAN Archives F.1 R.1 number 850, fig. 18, published with permission of IA RAN).

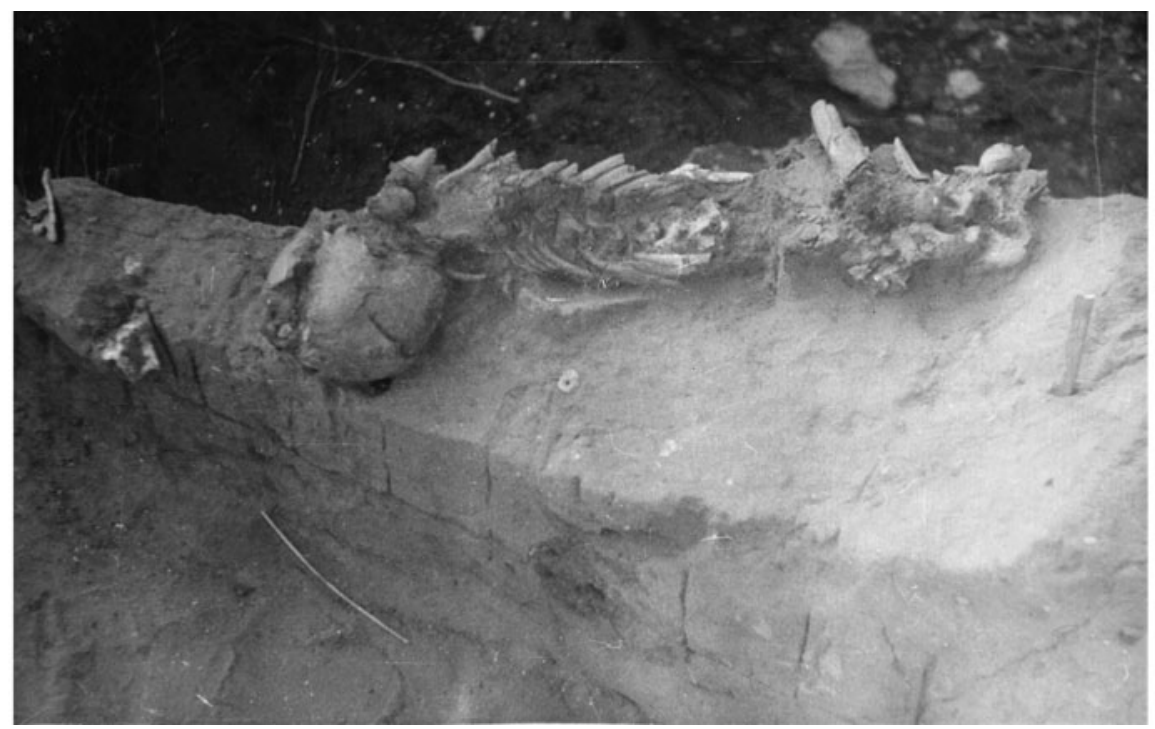

Figure 6. Photograph showing the Kostënki 18 human remains (view from the south-east) (photograph: Rogachëv 1953, IA RAN Archives F.1 R.1 number 850, fig. 19, published with permission of IA RAN).

\section{The radiocarbon age of the Kostënki 18 burial}

Despite intensive efforts, the direct dating of Upper Palaeolithic human bone has proved challenging, especially when glues and other preservatives have been applied. These can (C) Antiquity Publications Ltd, 2017 
be very difficult to remove from samples prior to radiocarbon dating, and, if incompletely removed, can lead to results that are offset by thousands of years from the sample's true
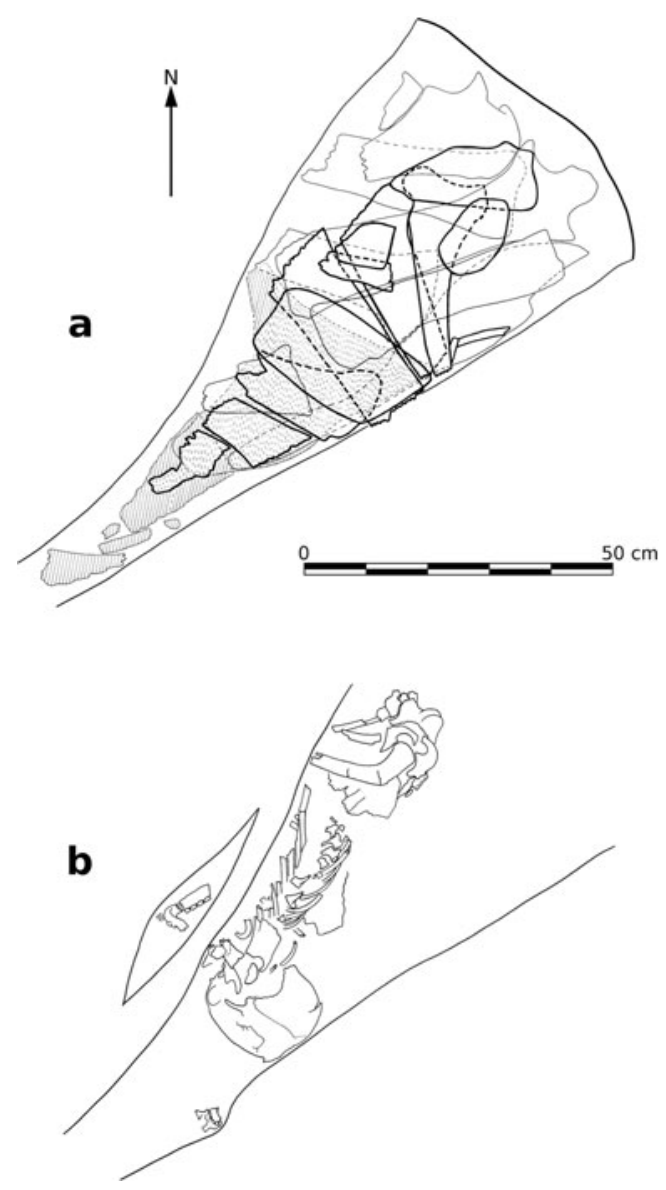

Figure 7. Plan of: a) the bones found above the skeleton, and b) the recovered skeleton itself. (Modified after a figure by A.N. Rogachëv, IIMK RAN Archives, 1953, photograph number: O.2068-15, published with permission of IIMK $R A N$.) radiocarbon age (see Jacobi \& Higham 2008; Marom et al. 2012, 2013).

In an attempt to address this problem, single amino acid radiocarbon dating has been developed and applied to Palaeolithic human material, with mostly encouraging results (Marom et al. 2012, 2013; Nalawade-Chavan et al. 2014). The method involves the separation of the amino acids from a bone collagen sample using preparative high-performance liquid chromatography (HPLC) and isolation of the amino acid hydroxyproline (Hyp), which is almost only ever naturally found in mammalian collagen. By isolating this amino acid, all potential contaminants (except collagen-based glues or preservatives) can be excluded. Due to the often small size of the extracted hydroxyproline fraction, the samples must be dated using AMS methods (McCullagh et al. 2010). Finally, the radiocarbon dates obtained are corrected to compensate for the additional 'background' input of carbon related to the use of HPLC (Nalawade-Chavan et al. 2014).

Many of the human remains excavated from Kostënki-Borshchëvo during the mid twentieth century were conserved with glues and preservatives. This is certainly the case for the Kostënki 18 skeleton, which was visibly heavily treated with glue. The previous dates from the skeleton are not in statistical agreement: $21020 \pm 180{ }^{14} \mathrm{C}$ BP $(\mathrm{OxA}-7128)$ and $19830 \pm 120{ }^{14} \mathrm{C} \mathrm{BP}$ (GrA-9304) (Table 1). To produce a more reliable age estimate, we conducted single amino acid radiocarbon dating on a sample of rib bone fragments from the collections held at the Institute for the History of Material Culture (IIMK) in Saint Petersburg. The approach was based on that previously outlined by Nalawade-Chavan et al. (2014), including their date correction algorithm. The final corrected result of $23440 \pm 150$ ${ }^{14} \mathrm{C}$ BP (OxA-X-2666-53 (Hyp)) is more than 2000 radiocarbon years older than the older of the two previous dates (Table 2). Using the IntCal13 curve and OxCal v4.2, a calibrated age of $27840-27390$ cal BP $(95.4 \%$ probability $)$ or $27740-27510 \mathrm{cal}$ 


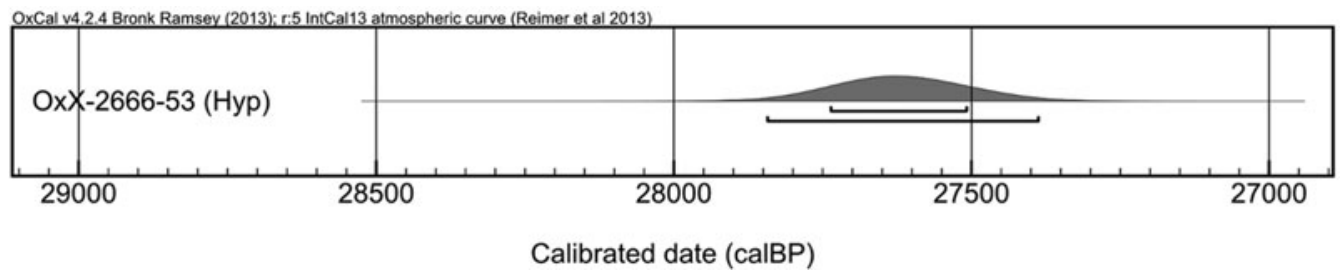

Figure 8. The new date for the Kostënki 18 human remains (rib sample) calibrated against IntCal13; plot generated using OxCal v4.2. Brackets below plot indicate $95.4 \%$ and 68.2\% probability ranges (Bronk Ramsey 2009; Reimer et al. 2013).

Table 1. Previously published radiocarbon dates for Kostënki 18 ranked by age BP.

\begin{tabular}{lcll}
\hline $\begin{array}{l}\text { Laboratory } \\
\text { code }\end{array}$ & $\begin{array}{c}{ }^{14} \mathrm{C} \text { age } \mathrm{BP} \pm 1 \sigma \\
\text { error }\end{array}$ & Sample material & Reference \\
\hline OxA-7128 & $21020 \pm 180$ & Human vertebra from burial & Sinitsyn et al. 1997 \\
GIN-8032 & $20600 \pm 140$ & Mammoth bone from burial & Sinitsyn et al. 1997 \\
GrA-9304 & $19830 \pm 120$ & Human vertebra from burial & Sinitsyn 2004 \\
GIN-8576 & $19300 \pm 200$ & Mammoth bone from burial & Sinitsyn et al. 1997 \\
GIN-8028 & $17900 \pm 300$ & Mammoth bone from burial & Sinitsyn et al. 1997 \\
\hline
\end{tabular}

BP (68.2\% probability) was produced (Figure 8; Bronk Ramsey 2009; Reimer et al. 2013).

\section{Discussion: Kostënki 18, the Kostënki-Avdeevo Culture and Early and Mid Upper Palaeolithic burials in European Russia}

The archaeological record for earlier Gravettian sites in Russia is sparse, with only three Gravettian sites radiocarbon-dated to the period between 28000 and $24000{ }^{14} \mathrm{C} \mathrm{BP}$ (Kostënki 8 Layer II, Kostënki 4 and Borshchëvo 5 Layer I: Reynolds et al. 2015). A greater number of sites are attributed to the later Gravettian Kostënki-Avdeevo Culture. This grouping is characterised by the presence of backed shouldered points, Kostënki knives and, frequently, female 'Venus figurine' sculptures. Decorated bone artefacts and particular features relating to the spatial organisation of sites have also been seen as important for the definition of the grouping. The large sites of Kostënki 1 Layer I, Avdeevo and Zaraisk are ordinarily attributed to the Kostënki-Avdeevo Culture, as are smaller sites including Kostënki 13 and Kostënki 14 Layer I, as well as Kostënki 18. The question of whether the sites of Khotylëvo-2 and Gagarino should be included is not fully resolved, while the site of Berdyzh in Belarus is often included on the basis of a relatively limited lithic assemblage (Gvozdover 1995; Gavrilov 2004; Sinitsyn 2007, 2013, 2015; see Klaric et al. 2015 for a detailed discussion of Kostënki knives).

Beyond Russia, the Kostënki-Avdeevo Culture is often connected with the 'shoulderedpoint horizon' sites of Central Europe, and sometimes these Central and Eastern European sites with shouldered points are combined under the umbrella term 'KostënkiWillendorfian', or a similar designation (e.g. Grigor'ev 1993; Gvozdover 1995; Svoboda 2007; Noiret 2013; see also Kozłowski 1986). The period post-dating the Kostënki-Avdeevo

(C) Antiquity Publications Ltd, 2017 
Table 2. The new radiocarbon date for Kostënki 18: results and calibrated age ranges. The corrected ${ }^{14} \mathrm{C}$ age has been adjusted to allow for the carbon contribution derived from the HPLC process (Nalawade-Chavan et al. 2014) and should be treated as the definitive result; calibrated against the IntCal13 curve using OxCal v4.2 (Bronk Ramsey 2009; Reimer et al. 2013).

\begin{tabular}{|c|c|c|c|c|c|c|c|c|}
\hline \multirow[b]{2}{*}{$\begin{array}{l}\text { Laboratory } \\
\text { code }\end{array}$} & \multirow[b]{2}{*}{$\begin{array}{c}\text { Uncorrected } \\
{ }^{14} \mathrm{C} \text { age } \mathrm{BP} \pm 1 \sigma \text { error }\end{array}$} & \multirow[b]{2}{*}{$\begin{array}{c}\text { Corrected } \\
{ }^{14} \mathrm{C} \text { age } \mathrm{BP} \pm 1 \sigma \text { error }\end{array}$} & \multirow[b]{2}{*}{$\begin{array}{l}\text { Sample } \\
\text { material }\end{array}$} & \multirow[b]{2}{*}{$\begin{array}{l}\text { C:N ratio } \\
\text { (Hyp) }\end{array}$} & \multirow[b]{2}{*}{$\begin{array}{c}\delta^{13} \mathrm{C}(\%) \\
(\mathrm{Hyp})\end{array}$} & \multirow[b]{2}{*}{$\begin{array}{c}\delta^{15} \mathrm{~N}(\%) \\
(\mathrm{Hyp})\end{array}$} & \multicolumn{2}{|c|}{ Calibrated age range } \\
\hline & & & & & & & $\begin{array}{c}68.2 \% \\
\text { probability }\end{array}$ & $\begin{array}{c}95.4 \% \\
\text { probability }\end{array}$ \\
\hline $\begin{array}{l}\text { OxA-X-2666-53 } \\
\text { (Нyp) }\end{array}$ & $23230 \pm 150$ & $23440 \pm 150$ & $\begin{array}{l}\text { Human } \\
\text { rib bones }\end{array}$ & 5.4 & -24.7 & 14.9 & $\begin{array}{c}27740-27510 \\
\text { cal BP }\end{array}$ & $\begin{array}{c}27840-27390 \\
\text { cal BP }\end{array}$ \\
\hline
\end{tabular}


Culture in Russia is not well understood, although some Kostënki sites that apparently date to the very end of the MUP or the beginning of the Late Upper Palaeolithic appear to be distinct from Gravettian sites and are attributed to the Zamiatnin Culture (Anikovich et al. 2008; Bessudnov 2013; Sinitsyn 2015).

The Upper Palaeolithic lithic assemblage of Kostënki 18, found mostly during the 1959 excavations (i.e. in a separate year and area to the burial), totals more than 1000 pieces, of which over 100 are retouched. The retouched assemblage includes backed bladelets, burins and nine complete and 42 possible fragmentary shouldered points (Rogachëv 1959). Although they vary somewhat in form and size, similarities have been seen between these shouldered points and those from Layer I at neighbouring Kostënki 1 (Rogachëv \& Beliaeva 1982; Bessudnov 2009). The presence of 28 complete and fragmentary Kostënki knives from Kostënki 18 has also been noted (Rogachëv 1959; Rogachëv \& Beliaeva 1982).

As outlined above, it is difficult to establish an association between the Kostënki 18 burial and the Kostënki 18 cultural layer, and hence with the Kostënki-Avdeevo Culture. There are no grave goods that can be used to link the burial with the cultural layer, and beyond their presence in the same broad geological unit, there is no stratigraphic information demonstrating an association. Any argument for contemporaneity of the burial and the other archaeological material at Kostënki 18 must therefore rely on dating evidence.

No radiocarbon dates are available for the Kostënki 18 cultural layer: only material from the burial has produced published dates (Table 1). The principal sites of the KostënkiAvdeevo Culture-Kostënki 1 Layer I, Avdeevo and Zaraisk-have each provided more than 25 dates (Damblon et al. 1996; Sinitsyn et al. 1997; Amirkhanov 2000; Abramova et al. 2001; Vermeersch 2017). At each site, the dates span a rather wide chronological range, which is probably due to the difficulty in producing accurate radiocarbon dates for this period (Damblon et al. 1996; Higham 2011). In our experience, and as borne out by redating work (e.g. Douka et al. 2010; Reynolds et al. 2015), the most ancient dates for each of the Kostënki sites or layers can generally be treated as more accurate than younger dates. This is because erroneous dates for this period tend to appear younger, rather than older, than the true ages of the samples (Higham 2011), and hence, for any given layer, more recent dates need to be treated with greater caution than more ancient dates.

The most ancient published dates for Kostënki 1 Layer I are around $24000-23500{ }^{14} \mathrm{C}$ $\mathrm{BP}$, as compared with around $23500-22000{ }^{14} \mathrm{C}$ BP for Avdeevo and around $23000-$ $22000{ }^{14} \mathrm{C}$ BP for Zaraisk (Damblon et al. 1996; Sinitsyn et al. 1997; Amirkhanov 2000; Abramova et al. 2001; Vermeersch 2017). Taken together these suggest an age range of c. 24000-22 $000{ }^{14} \mathrm{C} \mathrm{BP}$ for the Kostënki-Avdeevo Culture (c. 28 500-26000 cal BP when calibrated against the IntCal13 curve using OxCal v4.2; Bronk Ramsey 2009; Reimer et al. 2013). The new date for the Kostënki 18 burial $\left(23440 \pm 150{ }^{14} \mathrm{C}\right.$ BP; OxA-X-2666-53 (Hyp); Table 2) indicates contemporaneity with the Kostënki-Avdeevo Culture and, by extension, broad contemporaneity with the Kostënki 18 cultural layer.

It is striking that all four of Kostënki's Kostënki-Avdeevo Culture sites-Kostënki 18, Kostënki 1 Layer I, Kostënki 13 and Kostënki 14 Layer I-are found within Pokrovskii Log, with the first three found within only a few hundred metres of each other (Figure 2). Of these sites, Kostënki 1 Layer I shows evidence for the most intensive occupation. Here, two complexes of features were found: parallel lines of hearths surrounded by pits and (C) Antiquity Publications Ltd, 2017 
concentrations of archaeological material (Klein 1969; Rogachëv et al. 1982). The eastern complex alone covered more than $600 \mathrm{~m}^{2}$ and represents a significant area of human activity, with a large lithic assemblage of over 40000 pieces, as well as osseous material and faunal remains (Rogachëv et al. 1982; Anikovich et al. 2008). Activity at the other three KostënkiAvdeevo Culture sites in Pokrovskii Log appears to have been much more limited. As a result, it has been proposed that Kostënki 18, Kostënki 1 Layer I and Kostënki 13 represent parts of a single settlement complex centred on Kostënki 1 (Sinitsyn 2007, 2013; Anikovich et al. 2008; Bessudnov 2009; but see Amirkhanov et al. 2001). The new date does not contradict these interpretations.

As stated above, we reserve the term 'Gravettian' for MUP assemblages showing evidence of the systematic production of backed lithics. If we use this definition, and accept a link between the Kostënki 18 human remains and the lithic assemblage found at the site, the Kostënki 18 burial stands alone among the corpus of EUP/MUP burials in European Russia in being associated with a Gravettian archaeological assemblage. The ochre-stained burial from Kostënki 14, which has previously been described as MUP (e.g. Pettitt 2011; RielSalvatore \& Gravel-Miguel 2013), is now dated firmly to the EUP (Table 3; Marom et al. 2012). At Sungir', the burial of an adult male (Sungir' 1) and a second burial of a child and young adolescent (Sungir' 2/3) were particularly rich in personal ornaments and grave goods (Bader 1967, 1970; Trinkaus et al. 2014). These remains have now produced dates close to the boundary between the MUP and EUP (Table 3; Marom et al. 2012; NalawadeChavan et al. 2014), and the site's lithic assemblage is very clearly non-Gravettian (Bader 1978).

The burials from Kostënki 2, 15 and 12 are probably of MUP age, but none are associated with a Gravettian assemblage. The partially preserved adult male skeleton from Kostënki 2 was found within a round mammoth-bone construction, with further human bones, assumed to be from the same individual, found disarticulated outside the structure (Boriskovskii 1955; Boriskovskii \& Dmitrieva 1982). Kostënki 2 is generally included in the Zamiatnin Culture, and is therefore thought to post-date Kostënki's Gravettian assemblages (Klein 1969; Anikovich et al. 2008; Bessudnov 2013; Sinitsyn 2015). At Kostënki 15, the burial of a young child included grave goods that help to link it with the site's (nonGravettian) Gorodtsovian archaeological layer (Klein 1969; Sinitsyn 2004). The chronology of Gorodtsovian assemblages is still not well defined, but they are thought, on the grounds of geological association and radiocarbon dating, to pre-date the Kostënki-Avdeevo Culture, and be closer in age to the Early Gravettian Layer II of Kostënki 8 (Anikovich et al. 2008; Sinitsyn 2013, 2015). Lastly, the skeleton of a neonate from Kostënki 12 was apparently directly associated with the site's Layer I, which is also usually described as Gorodtsovian (Sinitsyn 2004; Anikovich et al. 2008: 139).

Kostënki 18 is therefore the only known burial in European Russia that can reasonably be associated with a Gravettian lithic assemblage. This should of course be understood in the context of the overall relative paucity of Gravettian assemblages in Russia, particularly from the period prior to $24000{ }^{14} \mathrm{C} \mathrm{BP}$, but the situation is certainly striking given the apparent link between Gravettian assemblages and human burials in the archaeological record farther west (Formicola 2007; Henry-Gambier 2008; Pettitt 2011; Riel-Salvatore \& Gravel-Miguel 2013). Burials in European Russia are instead associated with numerous EUP and MUP

(C) Antiquity Publications Ltd, 2017 
Table 3. Previously published direct single amino acid radiocarbon dates for Early/Mid Upper Palaeolithic human burials from European Russia. Corrected ${ }^{14} \mathrm{C}$ ages have been adjusted to allow for the carbon contribution derived from the HPLC process (Marom et al. 2012; Nalawade-Chavan et al. 2014). ${ }^{*}$ Laboratory codes erroneously cited in original publication as OxX-rather than OxA-X-. ${ }^{\dagger}$ These dates were combined (with one other date, not presented here) prior to correction: see source for details.

\begin{tabular}{|c|c|c|c|c|c|}
\hline & $\begin{array}{l}\text { Laboratory } \\
\text { code }\end{array}$ & $\begin{array}{c}\text { Uncorrected } \\
{ }^{14} \mathrm{C} \text { age } \mathrm{BP} \pm 1 \sigma \text { error }\end{array}$ & $\begin{array}{c}\text { Corrected } \\
{ }^{14} \mathrm{C} \text { age } \mathrm{BP} \pm 1 \sigma \text { error }\end{array}$ & $\begin{array}{l}\text { Sample } \\
\text { material }\end{array}$ & Reference \\
\hline Kostënki 14 & $\begin{array}{l}\text { OxA-X-2395-15 } \\
\text { (Hyp) }\end{array}$ & $33250 \pm 500$ & $33900 \pm 550$ & Human bone & $\begin{array}{l}\text { Marom } \\
\quad \text { et al. } 2012\end{array}$ \\
\hline Sungir' 1 & $\begin{array}{l}\text { OxA-X-2464-12 } \\
\text { (Нyp) }\end{array}$ & $28650 \pm 400$ & $28890 \pm 430$ & Human bone & $\begin{array}{l}\text { Nalawade-Chavan } \\
\text { et al. } 2014\end{array}$ \\
\hline Sungir' 2 & $\begin{array}{l}\text { OxA-X-2395-6 } \\
(\text { Hyp })^{*}\end{array}$ & $30100 \pm 550$ & $30700 \pm 350^{\dagger}$ & Human bone & $\begin{array}{l}\text { Marom } \\
\quad \text { et al. } 2012\end{array}$ \\
\hline Sungir' 3 & $\begin{array}{l}\text { OxA-X-2395-7 } \\
(\text { Hyp) }\end{array}$ & $30000 \pm 550$ & $30700 \pm 350^{\dagger}$ & Human bone & $\begin{array}{l}\text { Marom } \\
\quad \text { et al. } 2012\end{array}$ \\
\hline Sungir' 4 & $\begin{array}{l}\text { OxA-X-2462-52 } \\
\text { (Нyp) }\end{array}$ & $29670 \pm 289$ & $29820 \pm 280$ & Human bone & $\begin{array}{l}\text { Nalawade-Chavan } \\
\text { et al. } 2014\end{array}$ \\
\hline
\end{tabular}


archaeological cultures, which appear substantially differentiated in their lithic assemblages. Furthermore, the apparent simplicity of the Kostënki 18 burial is notable, as the surviving part of the grave lacked any personal ornamentation, pigmentation or identifiable grave goods other than the mammoth bones. This contrasts with the burials from Kostënki 14, 15 and especially Sungir'.

\section{Conclusions}

In the absence of informative grave goods or a clear stratigraphic association, the precise relationship between the Kostënki 18 child burial and the site's Kostënki-Avdeevo Culture assemblage cannot be established beyond doubt. The new radiocarbon date for the burial of $23440 \pm 150{ }^{14} \mathrm{C} \mathrm{BP}$ (OxA-X-2666-53 (Hyp)) is, however, consistent with the probable age of the Kostënki-Avdeevo Culture, and thus supports a link between the two. The date is also consistent with the proposition that the Kostënki 18 burial was positioned on the margins of a large late MUP occupation area in Pokrovskii Log centred on Kostënki 1.

EUP and MUP burials in European Russia are documented in diverse cultural contexts, and the earliest of them pre-date the appearance of Gravettian assemblages anywhere in Europe. Burials at Kostënki 14 and Sungir' are now radiocarbon-dated to the EUP or EUP/MUP boundary; those from Kostënki 2, 12 and 15 apparently date to different periods of the MUP, but none are associated with a Gravettian assemblage. At present, Kostënki 18 is the only Russian site where a human burial can be connected to a lithic assemblage reasonably described as Gravettian, a noteworthy situation given the rich record of Gravettian burials known farther to the west. This complexity in the Russian record is important for understanding the significance of EUP and MUP burials in Europe. Most obviously, the Russian evidence shows that we cannot make a straightforward link between the appearance of Gravettian archaeological assemblages and modern human burials.

\section{Acknowledgements}

We thank the following bodies for their financial support: the Fondation Fyssen; the Leverhulme Trust; the RFBR (grants 14-06-31134_mol-a and 17-06-00319a); and the ERC (ERC-2012-AdG-324139-PalaeoChron). We are very grateful to several colleagues for their remarks on drafts of the text, particularly Laurent Klaric, and to the reviewers for their helpful comments. Any mistakes or shortcomings in the text naturally remain our responsibility. We thank Maria Medvedeva and Natalia Lazarevskaya for their assistance with finding archive material. We also thank Daniel Comeskey and Kathryn Mears (Research Laboratory for Archaeology \& the History of Art) for help with preparation of the sample for dating. This publication is a contribution to the Leverhulme Trust project RPG-2012-800.

\section{References}

Abramova, Z.A., G.V. Grigorieva \& G.I. Zaitseva. 2001. The age of Upper Paleolithic sites in the Middle Dnieper River basin of Eastern Europe. Radiocarbon 42: 1077-84. https://doi.org/10.1017/S0033822200041734

Amirkhanov, Kн.A. 2000. Zaraiskaia stoianka. Moskva: Nauchnyi mir (in Russian).
Amirkhanov, Kh.A., S.Iu. Lev \& A.B. Seleznëv. 2001. Problema 'paleoliticheskoi derevni' kostënkovskoi kul'tury v svete issledovanii Zaraiskoi stoianki. Kratkie soobshcheniia instituta arkheologii 211: 5-16 (in Russian). 
Anikovich, M.V., V.V. Popov \& N.I. Platonova. 2008. Ranniaia pora verkhnego paleolita po materialam Kostënkovsko-Borshchëvskogo raiona, in M.V. Anikovich, V.V. Popov \& N.I. Platonova (ed.) Paleolit Kostënkovsko-Borshchëvskogo raiona $v$ kontekste verkhnego paleolita Evropy: 74-142. Sankt-Peterburg: Nestor-Istoriia (in Russian).

BADER, O.N. 1967. Pogrebeniia v verkhnem paleolite i mogila na stoianke Sungir'. Sovetskaia arkheologiia 1967(3): 142-59 (in Russian).

- 1970. Vtoraia paleoliticheskaia mogila na Sungire, in B.A. Rybakov (ed.) Arkheologicheskie otkrytiia 1969 goda: 41-43. Moskva: Nauka (in Russian).

- 1978. Sungir'_verkhnepaleoliticheskaia stoianka. Moskva: Nauka (in Russian).

Bader, N.O. \& Iu.A. Lavrushin. (ed.). 1998. Pozdnepaleoliticheskoe poselenie Sungir' (pogrebeniia i okruzhaiushchaia sreda). Moskva: Nauchnyi Mir (in Russian).

Bessudnov, A.A. 2009. Stoianka Kostënki 18 v kontekste kostënkovsko-avdeevoskoi kul'tury, in V.V. Kileinikov (ed.) Arkheologicheskie pamiatniki Vostochnoi Evropy: mezhvuzovskii sbornik nauchnykh trudov. Vypusk 13: 242. Voronezh: Nauchnaia Kniga (in Russian).

- 2013. Paleoliticheskie pamiatniki kontsa pleistotsena $\mathrm{v}$ basseine Verkhnego i Srednego Dona, in G.V. Sinitsyna (ed.) Problemy zaseleniia Severo-Zapada Vostochnoi Evropy v verkhnem $i$ final'nom paleolite (kul'turno-istoricheskie protsessy): 127-51. Sankt-Peterburg: IIMK RAN (in Russian).

BoriskovskiI, P.I. 1955. Raskopki paleoliticheskogo zhilishcha i pogrebeniia na stoianke Kostënki II v 1953 g. Sovetskaia Etnografiia 1955(1): 39-42 (in Russian).

Boriskovskit, P.I. \& T.N. DMitrieva. 1982. Kostënki 2 (stoianka Zamiatnina), in N.D. Praslov \& A.N. Rogachëv (ed.) Paleolit

Kostënkovsko-Borshchëvskogo raiona na Donu. 1879-1979: nekotorye itogi polevykh issledovanii: 67-72. Leningrad: Nauka (in Russian).

Bronk Ramsey, C. 2009. Bayesian analysis of radiocarbon dates. Radiocarbon 51: 337-60. https://doi.org/10.1017/S0033822200033865

Damblon, F., P. Haesaerts \& J. van der Plicht. 1996. New datings and considerations on the chronology of Upper Palaeolithic sites in the Great Eurasiatic plain. Préhistoire Européenne 9: 177-231.

Djindjian, F., J. KozŁowski \& M. OtтE. 1999. Le paléolithique supérieur en Europe. Paris: Armand Colin.

Douka, K., T. Higham \& A. Sinitsyn. 2010. The influence of pretreatment chemistry on the radiocarbon dating of Campanian Ignimbrite-aged charcoal from Kostënki 14 (Russia). Quaternary Research 73: 583-87. https://doi.org/10.1016/j.yqres.2010.01.002
EINWÖGERER, T., M. HÄNdEL, C. Neugebauer-Maresch, U. Simon \& M. Teschler-Nicola. 2008. The Gravettian infant burials from Krems-Wachtberg, Austria, in K. Bacvarov (ed.) Babies reborn: infant/child burials in pre-and protohistory (British Archaeological Reports international series 1832): 15-19. Oxford: Archaeopress.

Formicola, V. 2007. From the Sunghir children to the Romito dwarf: aspects of the Upper Paleolithic funerary landscape. Current Anthropology 48: 446-53. https://doi.org/10.1086/517592

GavriLov, K.N. 2004. Tipologiia kammenykh orudii i kul'turnaia prinadlezhnost' Khotylëvskoi verkhnepaleoliticheskoi stoianki, in Kh.A. Amirkhanov (ed.) Problemy kamennogo veka Russkoi ravniny: 262-84. Moskva: Nauchnyi mir (in Russian).

Gerasimova, M.M. 1982. Paleoantropologicheskie nakhodki, in N.D. Praslov \& A.N. Rogachëv (ed.) Paleolit Kostënkovsko-Borshchëuskogo raiona na Donu. 1879-1979: nekotorye itogi polevykh issledovanii: 245-57. Leningrad: Nauka (in Russian).

Gerasimova, M.M., S.N. Astakhov \& A.A. Velichко. 2007. Paleoliticheskii chelovek, ego material'naia kul'tura i prirodnaia sreda obitaniia. Sankt-Peterburg: Nestor-Istoriia (in Russian).

Grigor'ev, G.P. 1993. The Kostënki-Avdeevo archaeological culture and the Willendorf-Pavlov-Kostënki-Avdeevo cultural unity, in O. Soffer \& N.D. Praslov (ed.) From Kostënki to Clovis: Upper Paleolithic-Paleo-Indian adaptations: 51-65. New York: Plenum.

Gvozdover, M. 1995. Art of the mammoth hunters: the finds from Avdeevo. Oxford: Oxbow.

Henry-Gambier, D. 2008. Comportement des populations d'Europe au Gravettien: pratiques funéraires et interprétations. Paléo 20: 399-438.

Higham, T.F.G. 2011. European Middle and Upper Palaeolithic radiocarbon dates are often older than they look: problems with previous dates and some remedies. Antiquity 85: 235-49. https://doi.org/10.1017/S0003598X00067570

Jacoвi, R.M. \& T.F.G. Higham. 2008. The 'Red Lady' ages gracefully: new ultrafiltration AMS determinations from Paviland. Journal of Human Evolution 55: 898-907. https://doi.org/10.1016/j.jhevol.2008.08.007

Klaric, L., S. Lev, Y. Giria \& M. Polanská. 2015. 'Couteaux de Kostienki et lames ameńageés par technique de Kostienki'. Retour sur un malentendu historique. Bulletin de la Société préhistorique française 112: 421-74.

KLEIN, R.G. 1969. Man and culture in the Late Pleistocene: a case study. San Francisco (CA): Chandler.

(C) Antiquity Publications Ltd, 2017 
Klima, B. 1988. A triple burial from the Upper Palaeolithic of Dolní Věstonice, Czechoslovakia. Journal of Human Evolution 16: 831-35. https://doi.org/10.1016/0047-2484(87)90027-3

Kozıowski, J.K. 1986. The Gravettian in Central and Eastern Europe. Advances in World Archaeology 5: 131-200.

Marom, A., J.S.O. McCullagh, T.F.G. Higham, A.A. Sinitsyn \& R.E.M. Hedges. 2012. Single amino acid radiocarbon dating of Upper Paleolithic modern humans. Proceedings of the National Academy of Sciences of the USA 109: 6878-81. https://doi.org/10.1073/pnas.1116328109

Marom, A., J.S.O. McCullagh, T.F.G. Higham \& R.E.M. Hedges. 2013. Hydroxyproline dating: experiments on the ${ }^{14} \mathrm{C}$ analysis of contaminated and low-collagen bones. Radiocarbon 55: 698-708. https://doi.org/10.1017/S0033822200057854

McCullagh, J.S.O., A. Marom \& R.E.M. Hedges. 2010. Radiocarbon dating of individual amino acids from archaeological bone collagen. Radiocarbon 52: 620-34. https://doi.org/10.1017/S0033822200045653

Mussi, M. 1995. Rituels funéraires dans les sépultures Gravettiens des grottes de Grimaldi et de la Grotte delle Arene Candide: un mise au point, in M. Otte (ed.) Nature et culture. Actes du colloque international de Liège, 13-17 décembre 1993 (ERAUL 68, volume II): 833-46. Liège: Université de Liège.

Nalawade-Chavan, S., J. McCullagh \& R. Hedges. 2014. New hydroxyproline radiocarbon dates from Sungir', Russia, confirm Early Mid Upper Palaeolithic burials in Eurasia. PLoS ONE 9: e76896. https://doi.org/10.1371/journal.pone.0076896

Noiret, P. 2013. De quoi Gravettien est-il le nom?, in M. Otte (ed.) Les Gravettiens: 29-64. Paris: Errance.

Peña Alonso, P. De la. 2012. A propósito del Gravetiense ... El paso de cultura a tecnocomplejo: un caso ejemplar de pervivencia particularista. Complutum 23(1): 41-62. https://doi.org/10.5209/ rev_cmpl.2012.v23.n1.39530

Pesesse, D. 2013. Le Gravettien existe-t-il ? Le prisme du système technique lithique, in M. Otte (ed.) Les Gravettiens: 67-104. Paris: Errance.

Peтtitt, P. 2011. The Palaeolithic origins of human burial. London: Routledge.

Praslov, N.D. \& A.N. Rogachëv (ed.). 1982. Paleolit Kostënkovsko-Borshchëvskogo raiona na Donu. 1879-1979: Nekotorye itogi polevykh issledovanii. Leningrad: Nauka (in Russian).
Reimer, P.J., E. Bard, A. Bayliss, J.W. Beck, P.G. Blackwell, C. Bronk Ramsey, C.E. Buck, H. Cheng, R.L. Edwards, M. Friedrich, P.M. Grootes, T.P. Guilderson, H. Haflidason, I. Hajdas, C. Hatté, T.J. Heaton, D.L. Hoffmann, A.G. Hogg, K.A. Hughen, K.F. Kaiser, B. Kromer, S.W. Manning, M. Niu, R.W. Reimer, D.A. Richards, E.M. ScotT, J.R. Southon, R.A. Staff, C.S.M. Turney \& J. van Der Plicht. 2013. IntCal13 and Marine13 radiocarbon age calibration curves $0-50,000$ years cal BP. Radiocarbon 55: 1869-87. https://doi.org/10.2458/azu_js_rc.55.16947

Reynolds, N., S.N. Lisitsyn, M.V. Sablin, N. Barton \& T. Higham. 2015. Chronology of the European Russian Gravettian: new radiocarbon dating results and interpretation. Quartär 62: 121-32.

Riel-Salvatore, J. \& C. Gravel-Miguel. 2013. Upper Palaeolithic mortuary practices in Eurasia: a critical look at the burial record, in L. Nilsson Stutz \& S. Tarlow (ed.) The Oxford handbook of the archaeology of death and burial: 303-46. Oxford: Oxford University Press. https://doi.org/10.1093/ oxfordhb/9780199569069.013.0017

RogachËv, A.N. 1953. Otchët o rabote razvedochnogo otriada Paleoliticheskoi ekspeditsii v Kostënkakh v 1953 godu. Unpublished report, IA RAN Archives, Moscow, F.1 R.1, no. 850 (in Russian).

- 1955. Pogrebenie drevnekamennogo veka na stoianke Kostënki XIV (Markina Gora). Sovetskaia Etnografiia 1955(1): 29-38 (in Russian).

- 1959. Otchët ob issledovanii paleolita v Kostënkakh v 1959 godu. Unpublished report, IA RAN Archives, Moscow, F.1 R.1, no. 1960 (in Russian).

Rogachëv, A.N. \& V.I. Beliaeva. 1982. Kostënki 18 (Khvoikovskaia stoianka), in N.D. Praslov \& A.N. Rogachëv (ed.) Paleolit Kostënkovsko-Borshchëvskogo raiona na Donu. 1879-1979: nekotorye itogi polevykh issledovanii: 186-90. Leningrad: Nauka (in Russian).

Rogachëv, A.N., N.D. Praslov, M.V. Anikovich, V.I. Beliaeva \& T.N. Dmitrieva. 1982. Kostënki 1 (stoianka Poliakova), in N.D. Praslov \& A.N. Rogachëv (ed.) Paleolit Kostënkovsko-Borshchëvskogo raiona na Donu. 1879-1979: nekotorye itogi polevykh issledovanii: 42-66. Leningrad: Nauka (in Russian).

Sinitsyn, A.A. 2004. Les sépultures de Kostënki: chronologie, attribution culturelle, rite funéraire, in M. Otte (ed.) La spiritualité. Actes du colloque de la commission 8 de l'UISPP (Paléolithique supérieur), Liège, 10-12 décembre 2003 (ERAUL 106): 237-44. Liège: Université de Liège.

- 2007. Variabilité du Gravettien de Kostienki (Bassin moyen du Don) et des territoires associés. Paléo 19: 181-202. 
- 2013. Gravett Kostënok v kontekste gravetta Vostochnoi Evropy, in G.V. Sinitsyna (ed.) Problemy zaseleniia Severo-Zapada Vostochnoi Evropy $v$ verkhnem i final'nom paleolite

(kul'turno-istoricheskie protsessy): 4-32.

Sankt-Peterburg: IIMK RAN (in Russian).

- 2015. Perspectives on the Palaeolithic of Eurasia: Kostënki and related sites, in N. Sanz (ed.) Human origin sites and the World Heritage convention in Eurasia, volume 1 (HEADS 4): 163-89. Paris \& Mexico City: UNESCO.
Sinitsyn, A.A., N.D. Praslov, Iu.S. Svezhentsev \& L.D. Sulerzhitskir. 1997. Radiouglerodnaia khronologiia verkhnego paleolita Vostochnoi Evropy, in A.A. Sinitsyn \& N.D. Praslov (ed.) Radiouglerodnaia khronologiia paleolita Vostochnoi Evropy i Severnoi Azii. Problemy i perspektivy: 21-66. Sankt-Peterburg: IIMK RAN (in Russian).

Svoboda, J. 2007. The Gravettian on the Middle Danube. Paléo 19: 203-20.

Trinkaus, E., A.P. Buzhilova, M.B. Mednikova \& M.V. Dobrovolskaya. 2014. The people of Sunghir: burials, bodies, and behavior in the Earlier Upper Paleolithic. New York: Oxford University Press.

Vermeersch, P.M. 2017. Radiocarbon Palaeolithic Europe Database, Version 21. Available at: http://ees.kuleuven.be/geography/projects/14cpalaeolithic/index.html (accessed 3 July 2017).

Received: 1 September 2016; Accepted: 1 December 2016; Revised: 12 December 2016 